\title{
Analysis of pre- and post-harvest practices of cowpea (Vigna unguiculata (L.) Walp.) in Benin
}

\author{
Ayihadji Paul F. HOUSSOU ${ }^{1}$, Bonaventure Cohovi AHOHUENDO ${ }^{2 *}$, \\ Pascal FANDOHAN ${ }^{1}$ and Djidjoho Joseph HOUNHOUIGAN ${ }^{3}$ \\ ${ }^{I}$ Programme de Technologies Agricoles et Alimentaires/ Institut National des Recherches Agricoles du Bénin, \\ 01 BP 128, Porto-Novo, Bénin. \\ ${ }^{2}$ Département de Production Végétale, Faculté des Sciences Agronomiques, Université d'Abomey-Calavi, 01 \\ BP 526 Cotonou, Bénin. \\ ${ }^{3}$ Département de Nutrition et Science Alimentaire, Faculté des Sciences Agronomiques, Université d'Abomey- \\ Calavi, 01 BP 526 Cotonou, Bénin. \\ Corresponding author, E-mail: ahohuendoc@daad-alumni.de; ahohuendoc@fsa.uac.bj,
} Tel: (00 229) 20248754 / $90015477 / 97449859$

\begin{abstract}
Cowpea is an important leguminous crop in Benin. Practices such as farming and storage conditions may influence the production yield and the grain quality. In this study, pre- and post-harvest practices of cowpea were analysed in relation to the quality of the grains. A survey on cowpea farming activities was conducted in the four agro-ecological zones of Benin. Three localities producing cowpea were selected in each agro-ecological zone. Information was obtained through individual interview and focus group discussions. Cowpea was mainly cultivated either as a monocrop or intercropped with maize and groundnuts in the four agro-ecological zones. Cowpea infestation by insects on farm and in storage was a major problem mentioned by farmers. To prevent insects' infestation in storage, cowpeas were thoroughly sundried at harvest and adequately sorted prior to storage. Such post-harvest practices could limit cowpea grains quality deterioration. Cowpeas were mainly stored in bags for about 3 months. About 23 cowpea based foods were identified. Major cowpea foods were ata (akara), moin-moin and adowe. Common processing operations included sorting, washing, dehulling of cowpeas, boiling and frying. These processing operations as practiced by processors are generally recognized as a good practice in food preparation.
\end{abstract}

(C) 2010 International Formulae Group. All rights reserved.

Keywords: Cowpea, production, storage, processing, insect, fungi.

\section{INTRODUCTION}

Cowpea (Vigna unguiculata (L.) Walp.) is the most predominant grain legume in many tropical countries. It provides the main and inexpensive source of protein for the poor urban and rural population (Alghali, 1991; IITA, 1994). In Africa, particularly in the western and the central regions, where it constitutes an essential element of the socio-economic daily life, cowpea production is very important.

In Benin, cowpea is cropped on $7 \%$ of the cultivated areas for the yearly cultures, with the Zou department producing more than 33\% of the total production; while $30 \%$ is produced 
by the three departments, Mono, Atlantic, Ouémé, of the South of the country (Allogni et al., 2004; ONASA, 2008). Unfortunately, cowpea yield is very low (about $760 \mathrm{~kg} / \mathrm{ha}$ ) (ONASA, 2008) due to its susceptibility to insect pest (Singh et al., 1997) and many diseases (Aveling and Adandonon, 2000), which not only reduced yield but also affect the quality of the harvest product (Bottenberg, 1995; Lalèyè, 2007).

In Benin, farming and post-harvest practices of cowpea remain traditional and can vary within locality or from one locality to another within the country. These practices have been only characterized in the eastern part of south Benin (Kossou et al., 2001). These authors reported that on the plateau region in south Benin, intercropping cowpea with maize (Zea mays L.) or cassava (Manihot esculenta Krantz) is practiced by the farmers to reduce cowpea insect pest populations and to prevent the building of a single pest population to unacceptable levels, while in the valley region, sole cropping is the dominant practice because the soil and the climatic conditions are not suitable. Furthermore, the farmers produce their own seeds or purchase planting materials from local markets. Although cowpea farmers' practices remain traditional in Benin, till date there is no study that report on the characterisation of those practices at country level. Detailed knowledge of cowpea agricultural practices and how cowpea is processed and used in Benin are necessary in order to appreciate them in relation to the quality of the grain.

The objectives of the present study were to inventory countrywide farmers' practices for production, storage and processing of cowpea and analyze those practices in relation to the quality of the grains.

\section{MATERIALS AND METHODS \\ Description of the study zone}

The study was conducted in the four agro-ecological zones of Benin (Figure 1). These zones as described by Hell et al. (2000a) are: (1) The Forest Mosaic Savannah (FMS) situated between the latitudes $6^{\circ} 30$ and $7^{\circ}$ North. The FMS is characterised by two rainy seasons (April to July and September to November) alternating with a long dry season (December-February), and a short dry season (July-august), which rarely exceeds two months. The average relative humidity exceeds 90\% almost every year, and the average annual temperature ranges from $25^{\circ} \mathrm{C}$ to $28{ }^{\circ} \mathrm{C}$ and can exceptionally reach $35^{\circ} \mathrm{C}$ $40{ }^{\circ} \mathrm{C}$; (2) the Southern Guinea Savannah (SGS), from the latitude $7^{\circ}$ to $8^{\circ}$ North. The SGS zone is a transition zone located between the North and the South of Benin, with the same seasonal pattern as the FMS, but less humid than the FMS zone. The average relative humidity ranges from $80 \%$ up to $85 \%$ during the rainy period of the year, and the maximum temperature more often between 28 ${ }^{\circ} \mathrm{C}$ and $32{ }^{\circ} \mathrm{C}$; (3) the Northern Guinea Savannah (NGS) situated between the latitudes $8^{\circ}$ and $11^{\circ}$ North, in contrast, is characterised by one rainy season (April to September). The relative humidity is only high (more than $70 \%$ ) during a short period running from July to September, very low during the harmattan wind (November to February), and high temperature $\left(28{ }^{\circ} \mathrm{C}\right.$ to 35 $\left.{ }^{\circ} \mathrm{C}\right)$; (4) the Sudan Savannah (SS) is comprised between the latitudes $11^{\circ}$ and $12^{\circ}$ North. The SS is the northernmost zone of the country, with one rainy season running from May to September. The climate is dry with low average relative humidity (less than 60\%) for several months, and high temperature (30 ${ }^{\circ} \mathrm{C}-42{ }^{\circ} \mathrm{C}$ ). This zone is at the limit of the Sahel, a very dry and warm zone in West Africa covering several countries including Niger, Burkina Faso, Mali and Senegal.

\section{Sites selection and survey}

In each agro-ecological zone three localities producing cowpea were randomly selected among the most important cowpea production districts of Benin (MAEP-DPP, 2005) and surveyed (Figure 1). These were Adjohoun, Kétou and Klouékanmè in the FMS zone; Bohicon, Savalou and Glazoué in the SGS zone; Parakou, Djougou and Ouaké 
in the NGS zone; Natitingou, Kandi and Malanville in the SS zone.

The data were collected in two phases, through the application of Participatory Research Appraisal tools and through other techniques including direct observation, focus group discussions, individual interviews and field visits using a semi-structure questionnaire. The focus group discussions were conducted with 10 to 15 cowpea farmers based on their availability in each locality during the first phase. Questions were asked about the cowpea cropping system, the cultivated varieties, the pest problems on farm and during storage, the storage practices, the processing, and the solutions applied to the encountered problems. During the second phase, quantitative data were collected especially on the factors that affect the quality of the grains such as grain rot, grain discoloration, grain perforation using an individual questionnaire in order to deepen information collected during the first phase. Due to the similarity of practices observed in the different zones, only the three localities of the FMS zone (Adjohoun, Kétou and Klouékanmè) where the production of cowpea is more important were chosen. A total of 30 producers and 15 processors were interviewed in the three localities.

During the survey, the farmers were requested to show the types of the cultivated cowpea varieties in use in their locality. In the NGS and SS zones, the survey was conducted with the help of interpreters.

\section{Statistical analyses}

Descriptive analyses of relative frequencies and means were performed on collected data using Excel software. The major constraints related to cowpea cultivation practices and storage were ranked based on score as described by Sodjinou et al. (2003).

Score $_{i}=\frac{\sum_{j} a j P i j}{\sum_{j} P i j}$

$P i j=$ Percentage of producers who attributed rank j " $j$ " to parameter " $i$ " $a j$ is such that $\mathrm{a}_{1}=\mathrm{n}, \mathrm{a}_{2}=\mathrm{n}-1, \mathrm{a}_{3}=\mathrm{n}-3 \ldots \ldots \mathrm{a}_{\mathrm{n}}$

$=1$

$\mathrm{n}=$ number of responders

$j=$ the rank attributed

\section{RESULTS}

\section{On-farm practices of cowpea}

Slight variations were observed in cowpea practices on-farms within the four agro-ecological zones of Benin. These practices are summarized in the Table 1. The most dominant cropping system of cowpea in the south was monocropping in the two agroecological zones. Indeed, $96 \%$ and $100 \%$ of the interviewed farmers in the FMS and NGS zones respectively practised monocropping (Table 1), while in the northern part of the country (SS, NGS), the two practices, monocropping and intercropping, were observed almost in the same proportion; for instance in the SS zone, $60 \%$ and $63 \%$ of the farmers practised monocropping and intercropping with maize or groundnut (Arachis hypogeae L.) respectively. In general, monocropping remained the dominant on-farm practice of cowpea cultivation in Benin.

Based on the seed coat colour, four dominant cowpea varieties were identified (Table 1). The white seed coat colour varieties named "Tchawé " or "flore" in "Fon" language or in "Wémè', (66\% and $70 \%$ in FMS and SGS zones respectively) and the maroon seed coat colour varieties named "Délékiwa" in "Nago" language or "Vohounvo" in "Wémè" (53\% and 60\% in FMS and SGS zones respectively) were the most dominant cowpea varieties cultivated in south and central Benin. The mottled type called "Toun " in "Dendi", or " Soui " in "Bariba", white-gray (70\% and 60\% in the NGS and SS zones respectively) and whiteblack seed coat colour (36\% and $36 \%$ in the NGS and SS zones respectively) were widespread in the two agro-ecological zones in north Benin.

According to the producers, the poor quality of cowpea grains on the field was caused by insects pests $(100 \%$ of the 
interviewed farmers) in the four agroecological zones followed by rodent attacks, $50 \%$ and $80 \%$ in the NGS and SS zones respectively, $80 \%$ and $43 \%$ in the SGS and FMS respectively (Table 1). Cotton insecticides such as the deltamethrin and the cyflutrin were mostly (at least $75 \%$ of the interviewed farmers) used to treat cowpea treatment on the fields. The use of botanical extracts made from leaves and seeds of neem (Azadirachta indica A. Juss), papaya (Carica papaya L.) and Hyptis suaveolens were low (less than 12\%). Approximately $16 \%$ of the farmers interviewed did not apply anything to solve the problems of field pests of cowpea. Rodenticide was employed by very few farmers to prevent rodent attacks; also various traps were set for this purpose. With a score of 2.63, cowpea's pod rot appeared to be the major quality problem of cowpea raised by the farmers followed by the pods perforation and discolouration with a score of 1.75 and 1.62 respectively (Table 2)

\section{Post harvest practices of cowpea}

The main post-harvest practices relating to storage and conservation of cowpea grains are shown in the Table 3 . After the harvest, cowpea grains were first dried and sorted (100\% of the respondents), then stored in bags and this practice was common in the four agro-ecological zones (Table 3). Among the storage containers used by the farmers, the granary was the less used structure in the different agro-ecosystems $(4.75 \%$ of the farmers). The average storage length was 3 months, and the cowpea infestation by the pest insects was the major problem identified by the farmers and these could be attributed to inappropriate storage conditions. The phosphure of aluminum (Phostoxin(C) was used by most farmers (more than $71 \%$ ) against insects for cowpea grain preservation during storage. The traditional methods of conservation such as the use of ash or pepper (Piper guineense L.), orange (Citrus sinensis (L.) obs) skin were employed by ca. $40 \%$ of interviewed farmers. However, the use of the traditional methods of conservation requires periodic sun drying (once at least every week) of the stock. The factors affecting stocked cowpea grains quality were similar in surveyed localities. The first three reasons of the bad cowpea grain quality during the storage were by order of importance: presence of insects in the stock, inappropriate dried grains and bad state of the storage structure with a score of 5.31, 4.62 and 3.48 respectively (Table 4). Sorting and thorough sun drying of cowpea before storage was practised by most producers to prevent or to reduce cowpea infestation during the storage. According to them, inadequate drying and sorting as well as the use of bad storage structures such as those made using wood, led to the fast deterioration of the cowpea quality during the storage.

\section{Processing}

Twenty three different cowpea based products or dishes were identified during the study (Table 5). These were boiled whole cowpea seed (Abobo, Vèhi), cooked ricecowpea mixture (Atassi/Watché), deep fried paste (Ata/Akara/kyo-banfoutou) with other variants (Doco, Ataclè, Gahou, Ata-houhou), cooked maize-cowpea mixture (Chichiga, Kilahaga, Zankpiti), steamed cowpea paste foods alone or mixed with yam flour (Moinmoin, tobani, tigakoundi), fritter made with flour (Yoyouè), cowpea purée (Adowè/Adovlo, Féchoida, lèlè), cowpea and yam or maize mixture (Adalu), cowpea soup (Akpada) and steamed cooked whole cowpea grain and maize flour mixture or maize grain-cowpea flour mixture ( $\left.\mathrm{Abla}^{l}, \mathrm{Abla}^{2} / \mathrm{Cowé}, \mathrm{Go}\right)$.

Except "Chichiga", "Tobani" and "Tigakoundi", were found only in the localities of the north Benin; the other products identified were found in all localities of the study. According to the processors interviewed, the preparation of all these dishes required prior sorting and washing of cowpea in order to remove dusts and bad quality grains (Rot, perforation and discolouration). In addition to sorting and washing, all cowpea foods were heat treated (Table 5) either through cooking/boiling in water or steam $(70 \%)$ or frying $(30 \%)$. Thirty five percent of processed foods required dehulling of cowpea (Table 5). 

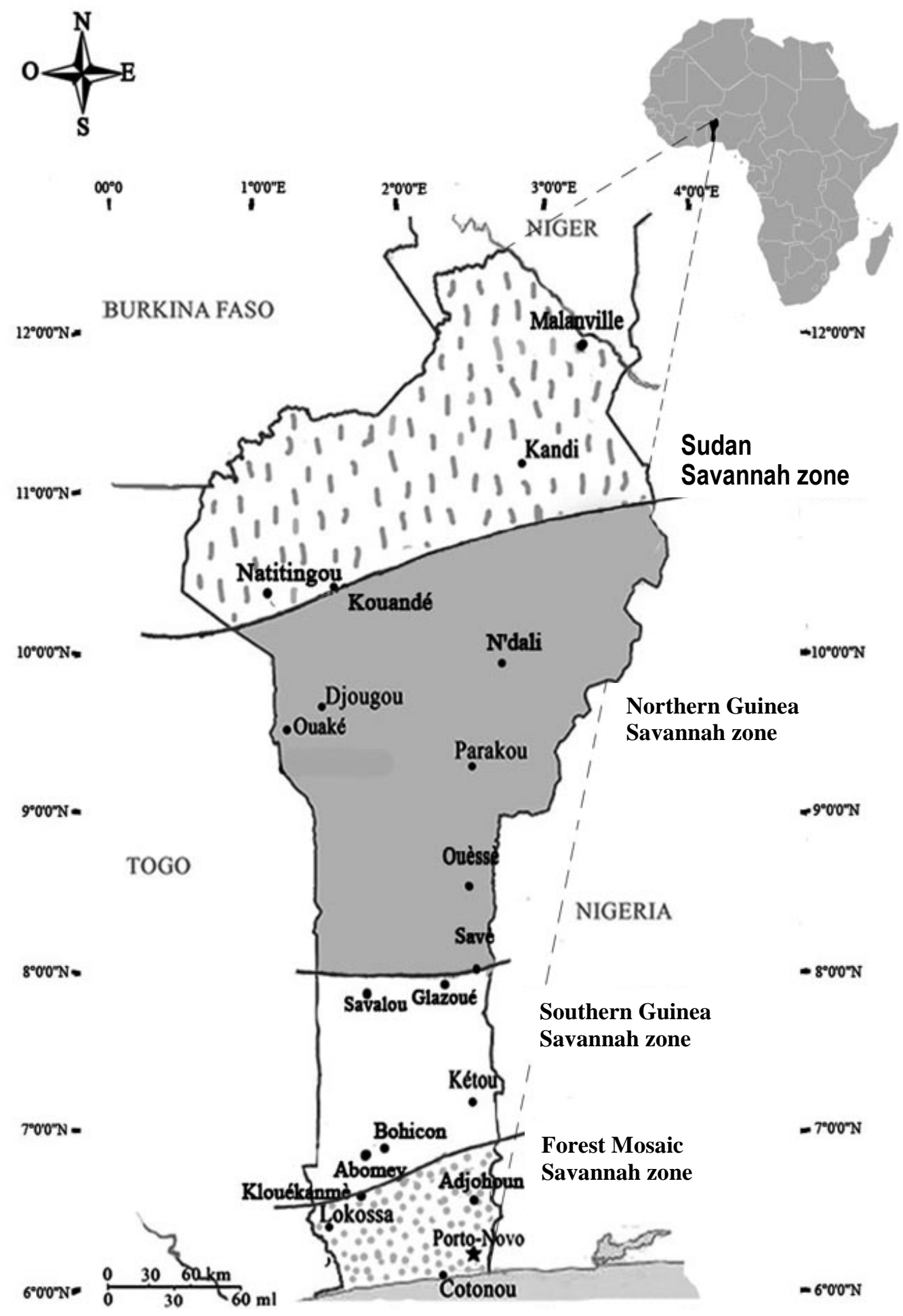

Figure 1: Map of the Republic of Benin with the different agro-ecological zones. 
A. P. F. HOUSSOU et al. / Int. J. Biol. Chem. Sci. 4(5): 1730-1741, 2010

Table 1: On-farm cowpea practices in different agro-ecological zones (\%, multiple answers were possible).

\begin{tabular}{|c|c|c|c|c|c|c|c|c|c|c|c|c|}
\hline & \multicolumn{2}{|c|}{ Cropping systems } & \multicolumn{4}{|c|}{ Variety cultivated } & \multicolumn{2}{|c|}{$\begin{array}{c}\text { Problems } \\
\text { encountered }\end{array}$} & \multicolumn{3}{|c|}{ Pest control methods } & \multirow[b]{2}{*}{ Pod drying } \\
\hline & $\begin{array}{c}\text { Mono- } \\
\text { croppin } \\
\mathbf{g}\end{array}$ & $\begin{array}{l}\text { Intercrop- } \\
\text { ping }\end{array}$ & White & Maroon & $\begin{array}{c}\text { White- } \\
\text { grey }\end{array}$ & $\begin{array}{l}\text { White- } \\
\text { black }\end{array}$ & $\begin{array}{l}\text { Insect } \\
\text { attack }\end{array}$ & Rodent & Chemical insecticide & $\begin{array}{c}\text { Botanical } \\
\text { Extracts }\end{array}$ & No treatment & \\
\hline NGS & 56 & 53 & 6 & 6 & 70 & 36 & 100 & 50 & 72 & 2 & 30 & 100 \\
\hline SS & 63 & 60 & 16 & 3 & 60 & 36 & 100 & 80 & 80 & 18 & 5 & 100 \\
\hline SGS & 100 & 46 & 70 & 60 & 6 & 0 & 100 & 80 & 80 & 15 & 10 & 100 \\
\hline FMS & 96 & 33 & 66 & 53 & 0 & 0 & 100 & 43 & 70 & 10 & 20 & 100 \\
\hline
\end{tabular}

Forest Mosaic Savannah (FMS); Southern Guinea Savannah (SGS); Northern Guinea Savannah (NGS); Sudan Savannah (SS).

Table 2: Farmer's responses concerning factors that affect cowpea quality on farm.

\begin{tabular}{lcccc}
\hline Factors & Rank 3 & Rank 2 & Rank 1 & Score \\
\hline Rot & 10.7 & 15.5 & 73.8 & 2,63 \\
Perforation & 31.3 & 62.7 & 6 & 1,75 \\
Discoloration & 58 & 21.8 & 20.2 & 1.62 \\
\hline
\end{tabular}


A. P. F. HOUSSOU et al. / Int. J. Biol. Chem. Sci. 4(5): 1730-1741, 2010

Table 3: Storage practices of cowpea in different agro-ecological zones (\%, multiple answers were possible).

\begin{tabular}{lcccccccccc}
\hline Zone & $\begin{array}{c}\text { Drying } \\
\text { and } \\
\text { sorting }\end{array}$ & Bags & $\begin{array}{c}\text { Metal } \\
\text { drum }\end{array}$ & $\begin{array}{c}\text { Plastic } \\
\text { drum }\end{array}$ & Granary & $\begin{array}{c}\text { 3 } \\
\text { Months }\end{array}$ & $\begin{array}{c}>\text { 3 } \\
\text { months }\end{array}$ & $\begin{array}{c}\text { Insect } \\
\text { attack }\end{array}$ & $\begin{array}{c}\text { Rot } \\
\text { Chemical } \\
\text { method }\end{array}$ & $\begin{array}{c}\text { Traditional } \\
\text { method }\end{array}$ \\
\hline NGS & 100 & 93 & 0 & 23 & 6 & 75 & 30 & 100 & 33 & 66 \\
SS & 100 & 100 & 0 & 0 & 13 & 83 & 17 & 100 & 50 & 65 \\
SGS & 100 & 93 & 10 & 20 & 0 & 80 & 30 & 100 & 30 & 76 \\
FMS & 100 & 90 & 40 & 26 & 0 & 73 & 27 & 100 & 35 & 80 \\
Mean & 100 & 94 & 12.5 & 17.25 & 4.75 & 77.75 & 26 & 100 & 42 & 71.75 \\
\hline
\end{tabular}

Table 4: Farmer's responses concerning the main factors affecting cowpea grains quality in storage.

\begin{tabular}{|c|c|c|c|c|c|c|c|}
\hline Factors & Rank 6 & Rank 5 & Rank 4 & Rank 3 & Rank 2 & Rank 1 & Score \\
\hline Insect (Bruchids) & 0.6 & 2.6 & 14.8 & 2.6 & 4.6 & 74.5 & 5.31 \\
\hline Drying quality & 0.4 & 1.6 & 6.5 & 25.3 & 57.3 & 8.5 & 4.62 \\
\hline State of storage structure & 6.5 & 18.6 & 14.6 & 43.2 & 14.1 & 2.5 & 3.48 \\
\hline State of storage medium & 3.0 & 15.2 & 46.4 & 18.7 & 10.5 & 6.4 & 3.38 \\
\hline Frequency of control* & 48.2 & 24.3 & 10.4 & 4.3 & 7.2 & 5.6 & 2.15 \\
\hline Inadequate collection of stored produce & 41.2 & 37.6 & 6.8 & 5.6 & 6.3 & 2.5 & 2.06 \\
\hline
\end{tabular}


A. P. F. HOUSSOU et al. / Int. J. Biol. Chem. Sci. 4(5): 1730-1741, 2010

Table 5: Major unit operations applied during cowpea processing.

\begin{tabular}{|c|c|c|c|c|c|}
\hline $\mathbf{N}^{\circ}$ & Operation cowpea foods & Sorting + washing & Dehulling & Heating-cooking & Frying \\
\hline 1 & Abobo & 1 & 0 & 1 & 0 \\
\hline 2 & Vehi & 1 & 0 & 1 & 0 \\
\hline 3 & Zankpiti & 1 & 0 & 1 & 0 \\
\hline 4 & Atassi/watché & 1 & 0 & 1 & 0 \\
\hline 5 & Abla $^{1}$ & 1 & 0 & 1 & 0 \\
\hline 6 & Adalu & 1 & 0 & 1 & 0 \\
\hline 7 & Doco & 1 & 0 & 0 & 1 \\
\hline 8 & Ataclè & 1 & 0 & 0 & 1 \\
\hline 9 & Yoyouè & 1 & 0 & 0 & 1 \\
\hline 10 & Féchoida & 1 & 0 & 1 & 0 \\
\hline 11 & Ata-houhou & 1 & 0 & 0 & 1 \\
\hline 12 & Chichiga & 1 & 0 & 1 & 0 \\
\hline 13 & Abla $^{2} /$ Cowé & 1 & 0 & 1 & 0 \\
\hline 14 & Akpada & 1 & 0 & 1 & 0 \\
\hline 15 & Gahou & 1 & 0 & 0 & 1 \\
\hline 16 & Tigakoundi & 1 & 1 & 1 & 0 \\
\hline 17 & Adowè/Adovlo & 1 & 1 & 1 & 0 \\
\hline 18 & kilahaga & 1 & 1 & 0 & 1 \\
\hline 19 & Tobani & 1 & 1 & 1 & 0 \\
\hline 20 & Go & 1 & 1 & 1 & 0 \\
\hline 21 & Ata/Akara/kyo-banfoutou & 1 & 1 & 0 & 1 \\
\hline 22 & moin-moin/kyokoko & 1 & 1 & 1 & 0 \\
\hline \multirow[t]{2}{*}{23} & Lèlè & 1 & 1 & 1 & 0 \\
\hline & Total (\%) & $23(100)$ & $8(35)$ & $16(70)$ & $7(30)$ \\
\hline
\end{tabular}

Legend: $1=$ operation is applied; $0=$ operation not applied. 


\section{DISCUSSION}

This study showed that in Benin, monocropping is the dominant practice adopted for cowpea production in the southern part of the country, particularly in the lowland valley (Adjohoun), whereas the two practices, monocropping and intercropping, are present almost in the same proportions in the north.

It was found during the survey that, generally cowpea is intercropped either with cassava or maize or groundnut. The clay soils in the lowland valley are not suitable for cropping cassava or groundnut as these are too compact. Similar observations were earlier made by Kossou et al. (2001) who mentioned that cassava could not be associated with cowpea in the lowland valley. This could be true with groundnut which needs light soils that are suitable for the pod development. Nevertheless cowpea associated with maize was also found in the FMS zone only on the plateau (Kétou) where water is available during the rainy season. In contrast, in the lowland valley, cowpea is only cropped offseason after flooding depending on the residual soil humidity. In this condition water is not too much available for the growth of certain crops like maize. That is why earlymaturing crop, like the white seed coat variety of cowpea, namely "Tchawé" or "flore", is preferred. Indeed, the importance of water availability for the maize production has been long time stressed by Escano et al. (1981) and Kone (1991).

According to the farmers interviewed, the dominant monocropping system observed in south is due to the disadvantages related to the intercropping practice well known by them. These are the difficulties in pests and weeds control in the fields as mentioned by the farmers during the survey and also described by Adandonon et al. (2005). In addition, Hell et al. (2003) showed that the association of cowpea with groundnut could increase the risk of fungi infection in the last culture to be cropped. Therefore the practice of monocropping of cowpea could contribute to limit the risk of infection by fungi.
The choice of the varieties to be cropped (based on the seed coat colour) in the different agro-ecological zones is highly related to the growth cycle, the yield (resistance to the pests and diseases), the nature of the associated crop and its market value based on the consumers' preference.

Almost all the (pre- and post-harvest) insects encountered on cowpea by farmers in the south as well as in the north Benin were previously reported by Kossou et al. (2001). The rodent attacks were also mentioned particularly on farm causing minor damages to the pods. The control of these cowpea ${ }^{2} \&$ in the fields is made with pesticides derived mostly from the cotton-growing sector. Cotton insecticides account for much of the six-fold increase in pesticide use in Benin over the last decade (Nathaniels, 2005), although they are rated as highly hazardous (class $1 \mathrm{~b}$ ) by the World Health Organization. In Benin, it is well known that cotton insecticides are widely diverted for use on food crops (Affognon, 2002). The reasons of the limited adoption of the alternative methods (neem and papaya leaves extracts) to control insects are due to the difficulties of the large area to be treated and the tedious crushing of the leaves and seeds as reported by the farmers.

At harvest, cowpea grains are not well dried for storage. In addition, the rotted grains and other undesired foreign material can be found in harvested cowpea. Therefore, the practices of sorting and drying in order to have good quality of grains with low moisture content for storage applied by the farmers before the storage should contribute to reduce the risks of cowpea infection by fungi. Indeed, these operations have been reported by Bankole and Adebanjo (2003) as being good and advisable practices against the infection and the development of fungi on grains in stock. The relatively short length of the storage (3 months on average) exercised by producers could also contribute to avoid the development of fungi on the grains. Of course, the development of fungi can occur in conditions of too long storage using 
traditional storage facilities often met in West African countries. For instance, according to Kaaya and Kyamuhangire (2006), the level of concentration in aflatoxin increases in the maize with the length of storage. Moreover, with respect to the conditions of storage and conservation of the grains, previous works showed a meaningful reduction of the fungi on stored products resulting on the utilization of chemical insecticides (Kavita and Reddy, 2000; Hell et al., 2000a). In the current study, a chemical insecticide called Phostoxin $\bigcirc$ " (Phosphure of aluminum) is the most conservative product utilized by farmers in Benin due to its higher efficacy as compared to other techniques of conservation according to the cowpea producers interviewed. Thus, the current practices of the farmers in Benin consisting of short length of storage (3 months) combine with the use of the insecticide Phostoxin $\bigodot$ should minimize the risk of cowpea grains infection during storage. Moreover it has been largely demonstrated by Houssou et al. (2008, 2009) that cowpea grains were very less susceptible to aflatoxins and fumonisins, indicating the good sanitation status of grains.

As far as processing is concerned, the different operations applied such as sorting, washing, dehulling, cooking and frying were revealed to have positive effect on mycotoxins reduction in the processed products (Shetty and Bhat 1999; Martin et al., 1999; Udoh et al., 2000; Hell et al., 2000b; Fandohan et al., 2006).

\section{Conclusion}

This study revealed the monocropping as the on-farm practice widely used in all agro-ecological zones in Benin. However, intercropping is also practised particularly in the two agro-ecological zones of the north. The post harvest practices such as, sorting and drying of grains before storage are in use by all cowpea producers. At the processing stage, sorting, washing, and dehulling are the main operations applied during cowpea based food preparation.
Based on the present result, cowpea products couldn't be considered as hazardous for the consumers.

\section{ACKNOWLEDGEMENTS}

This work is part of the doctoral dissertation and was done under the project "Capability Building for Research and Quality Assurance in Traditional Food Processing in West Africa" funded by the Danish International Development Assistance (DANIDA). We would like to thank particularly the farmers for the provided information and the extension officers for their technical assistance.

\section{REFERENCES}

Adandonon A, Aveling TA, Labuschagne N, Ahohuendo BC. 2005. Etiology and effect of environmental factors on damping-off and stem rot of cowpea in Benin. Phytoparasitica, 33: 65-72.

Affognon HD. 2002. Crop protection policy in Benin: factors influencing pesticide use. Pesticide Project Publications Series, Special Issue $\mathrm{N}^{\circ}$. Hannover: University of Hanover.

Alghali AM. 1991. Studies on cowpea farming practices in Nigeria, with emphasis on insect pest control. Tropical Pest Management, 37: 71-74.

Allogni WN, Coulibaly ON, Honlonkou AN. 2004. Impact des nouvelles technologies de la culture de niébé sur le revenu et les dépenses des ménages agricoles au Bénin. Bulletin de la Recherche Agronomique du Bénin, 44: 1-13.

Aveling TAS, Adandonon A. 2000. Pre and post-emergence of damping-off of cowpea caused by Phytium ultimum in South Africa. Plant Disease, 84: 912-922.

Bankole SA, Adebanjo A. 2003. Mycotoxins in food in West Africa: current situation and possibility of controlling it. African Journal of Biotechnologies, 2(9): 254263.

Bottenberg H. 1995. Farmers' perception of crops pests and pest control practices in 
rainfed cowpea cropping systems in Kano, Nigeria. International Journal of Pest Management, 41: 195-200.

Escano CR, Jones CA, Uehara G. 1981. Nutrient diagnosis in corn grown on hydric dystrandepts: I. Optimum tissue nutrient concentrations. Soil Science Society of America Journal, 45: 1135-1139.

Fandohan P, Ahouansou R, Houssou P, Hell K, Marasas WFO, Wingfield MJ. 2006. Impact of mechanical shelling and dehulling on Fusarium infection and fumonisin contamination in maize. Food Additives and Contaminants, 4(23): 415421.

Hell K, Cardwell KF, Setamou M, Poehling HM. 2000a. The influence of storage practices on aflatoxin contamination in maize in four agroecological zones of Benin, West Africa. Journal of Stored Product Research, 36: 365-382.

Hell K, Cardwell KF, Setamou M, Schulthess F. 2000b. Influence of insect infestation on aflatoxin contamination of stored maize in four agroecological regions in Benin. African journal of Entomology, 6: 169-177.

Hell K, Cardwell KF, Poehling HM. 2003. Relationship between management practices, fungal infection and aflatoxin for stored maize in Benin. Journal of Phytopathology, 151: 690- 698.

Houssou PA, Ahohuendo BC, Fandohan P, Kpodo K, Hounhouigan DJ, Jakobsen M. 2009. Natural infection of cowpea (Vigna unguiculata (L.) Walp.) by toxigenic fungi and mycotoxin contamination in Benin, West Africa. Journal of Stored Products Research, 45: 40-44.

Houssou PA, Schmidt-Heydt M, Geisen R, Fandohan P, Ahohuendo BC, Hounhouigan DJ, Jakobsen M. 2008. Cowpeas as growth substrate do not support the production of aflatoxin by Aspergillus sp. Mycotoxin Research, 24(2): 105-110.

IITA (International Institute of Tropical Agriculture). 1994. Characterization of disease and insect problems of legumes, $\mathrm{pp}$. 77-94. In Annual Report 1994 (Edited by IITA), IITA: Ibadan.

Kavita W, Reddy MU. 2000. Effect of chemicals on aflatoxin $\mathrm{B}_{1}$ production, germination and viability in maize and groundnuts. Journal of Research ANGRAU, 28: 57- 64.

Kaaya AN, Kyamuhangire W. 2006. The effect of storage time and agroecological zone on mould incidence and aflatoxin contamination of maize from traders in Uganda. Uganda Journal of Agricultural Sciences, 110: 217-223.

Kone D. 1991. Caractérisation du risque climatique de la culture du maïs en zone centre Côte d'Ivoire. Soil water Balance in the Sudano-Sahelian Zone (Proceedings of the Niamey Workshop, February 1991). IAHS Publ. no. 199.

Kossou D, Gbèhounou G, Ahanchédé A, Ahohuendo B, Bouraima Y, Van Huis A. 2001. Indigenous cowpea production and protection practices in Bénin. Insecte Science Application, 21(2): 123-132.

Lalèyè WD. 2007. Interaction de Baculovirus mavi NPV et du parasitoïde (Apanteles taragamae (Viereck)) (Hymenoptera : Braconidae) pour le contrôle de Maruca vitrata Fabricius (Lepidoptera : Pyralidae). Mémoire d'Ingénieur Agronome, Université d'Abomey-calavi, Bénin.

MAEP (Ministère de l'Agriculture, de l'Elevage et de la Pêche - Direction de la Programmation et de la Prospective). 2005. Annuaire statistique. Tome 1 Production Végétale.

Martin S, Homedes V, Sanchis V, Ramos AJ, Magan N. 1999. Impact of Fusarium moniliforme and $F$. proliferatum colonization of maize on calorific losses and fumonisin production under different environmental conditions. Journal of Stored Product Research, 35: 15-26.

Nathaniels NQR. 2005. Cowpea, farmer field schools and farmer-to-farmer extension: a Benin case study. Agricultural Research 
and Extension Network. Network paper $\mathrm{N}^{\circ} 148$. Overseas Development Institute. London, United Kingdom.

Office National d'Appui à la Sécurité Alimentaire (ONASA). 2008. Evaluation de la production vivrière 2007. Bénin : Ministère de l'Agriculture de l'Elevage et de la Pêche.

Shetty PH, Bhat RV. 1999. A physical method for segregation of fumonisincontaminated maize. Food Chemestry, 66: $371-374$.

Sodjinou E, Biaou G, Codjia JTC. 2003. Caractérisation du marché des escargots géants africains (achatines) dans les départements de l'Atlantique et du Littoral au Sud-Bénin, Tropicultura, 20: 83-86.

Singh BB, Mohan Raj DR, Dashiell KE, Jackai LEN. 1997. Advances in cowpea research. Co-publication for International Institute of Tropical Agriculture (IITA) and Japan International Research Center for Agricultural Sciences (JIRCAS). IITA, Ibadan, Nigeria. 460 p.

Udoh JM, Cardwell K, Ikotun T. 2000. Storage structure and aflatoxin content of maize in five agroecological zones of Nigeria. Journal of Stored Products Research, 36: 187-201. 